\title{
EVALUASI JURNAL ILMIAH
}

\section{Karnadi dan Ika Lestari}

\begin{abstract}
A scientific journal is needed as a medium in publishing the research findings which can be beneffited not only as an information to increase the knowledge but also as a reference for future researchers. The quality of the scientific journal, therefore, should be guaranteed from certain aspects such as the content, language, style, and periode. This evaluation research aimed at measing the quality of scientific journal published by The School of Education, State University of Jakarta, titled Jurnal Perspektif Ilmu Pendidikan based on the standards formulated by LIPI. The evaluation used quantitative approach and took place in The School of Education, State University of Jakarta, Penelitian ini menggunakan pendekatan kuantitatif. Tempat penelitian yaitu di Fakultas Ilmu Pendidikan Universitas. The evaluation, conducted as from April through October 2009, covered all publications of $2006-2009$. The result of the evaluation showed a number of requirements in puplising a scientific journlal based on LIPI standards, have not fulfilled, To be accredited as a scientific journal, this evaluation pointed out some steps to be taken by the editorial board of Jurnal Perspektif Ilmu Pendidikan.
\end{abstract}

Keywords: scientific journal, evaluation, accreditation standard.

\section{PENDAHULUAN}

\section{Latar Belakang Masalah}

Universitas Negeri Jakarta (UNJ) sebagai organisasi belajar merupakan salah satu bagian dari sistem pendidikan tinggi lokal, nasional, maupun internasional yang dapat berperan dalam pembangunan ilmu pengetahuan dan teknologi tidak saja berasal dari kontribusi pengelola universitas, lulusannya yang bermutu, akan tetapi juga dari hasil penelitiannya yang relevan terhadap pengembangan keilmuan dan kebutuhan pembangunan.

Hasil-hasil penelitian berupa artikel ilmiah maupun buku ajar perlu untuk disebarluaskan kepada para dosen maupun masyarakat di luar lingkungan UNJ. Khusus untuk publikasi artikel ilmiah, salah satu sistem komunikasi ilmiah yang perlu ditingkatkan adalah jurnal atau berkala ilmiah yang diterbitkan baik oleh organisasi profesi, departemen atau fakultas, maupun pusat-pusat studi yang secara teknis telah dinyatakan baik.

Oleh karena itu, dalam rangka mewadahi para dosen untuk melakukan penelitian, Fakultas Ilmu Pendidikan menerbitkan sebuah jurnal ilmiah yang berjudul Perspektif Ilmu Pendidikan. Jurnal Perspektif Ilmu Pendidikan diperuntukkan bagi dosen-dosen yang ingin memasukkan hasil penelitiannya dalam bidang pendidikan. Untuk menjaga kualitas jurnal ilmiah diperlukan suatu evaluasi atau penilaian dari badan pemberi akreditasi. Saat ini, Jurnal Perspektif
Ilmu Pendidikan memang belum dievaluasi dari badan pemberi akreditasi.

Evaluasi terhadap berkala ilmiah yang telah dilakukan oleh Dikti sejak tahun 1992/1993 menunjukkan bahwa penampilan sebagian besar berkala ilmiah yang ada di Indonesia belum sesuai dengan yang diharapkan. Dari sebagian besar berkala ilmiah masih perlu diperkuat segi mendasarnya, antara lain tersedianya artikel yang bermutu, proses penyuntingan, dan kemampuan memasarkan atau penyebarannya. Kemampuan menulis masyarakat ilmiah di Indonesia dirasakan masih belum optimum sehingga kemauan untuk menulis artikel ilmiah yang dipublikasikan dalam berkala bermutu yang terakreditasi masih terus harus dipacu (Depdiknas, 2006).

Suatu survei oleh Scientific American di tahun 1994 menunjukkan bahwa kontribusi ilmuwan Indonesia pada khasanah pengembangan dunia ilmu setiap tahunnya hanyalah sekitar $0.012 \%$, yang jauh berada di bawah Singapura yang berjumlah $0.179 \%$, apalagi kalau dibandingkan dengan USA yang besarnya lebih dari 25\%. Oleh beberapa pengamat barat, jerih payah upaya ilmuwan Indonesia untuk ikut berkontribusi terhadap perkembangan khasanah ilmiah dunia diistilahkan lost science in the third world. Pernyataan bernada sumbang ini terutama disebabkan karena hasil yang disumbangkan mereka tidak sampai ke hadapan mitra bestari sesama ilmuwannya yang sebidang hanya karena ditulis dalam berkala yang berjangkauan terbatas (Depdiknas, 
2009).

Keterbatasannya disebabkan karena sempitnya sirkulasi persebaran publikasi dan berkala, tiras yang sedikit sehingga tidak dilanggan oleh perpustakaan utama pusat kegiatan ilmiah internasional, dan penggunaan bahasa yang tak terbacakan secara luas. Sebagai akibatnya judul tulisan karya ilmuwan Indonesia pun tak tertampilkan dalam layanan cepat bibliografi dan kata kuncinya tak terambil oleh penyedia pindaian internet. Dapatlah dimengerti jika ilmuwan Indonesia sudah dicap hanya merupakan jago kandang. Oleh karena itu, tidaklah mengherankan jika berkala ilmiah Indonesia yang terdaftar dalam liputan Science Citation Index masih dapat dihitung dengan jari sebelah tangan (Depdiknas, 2009).

Oleh karena itu, Jurnal Perspektif Ilmu Pendidikan Fakultas Ilmu Pendidikan ingin berupaya ke arah berkala bermutu yang terakreditasi agar naskahnaskah penelitiannya dapat memberikan kontribusi terhadap perkembangan ilmu pengetahuan dan teknologi bagi dunia pendidikan di Indonesia. Dengan demikian, maka perlu diadakannya penelitian yang berkaitan dengan evaluasi Jurnal Perspektif Ilmu Pendidikan agar dapat mengukur bagaimana mutu Jurnal Perspektif Ilmu Pendidikan ditinjau dari pedoman akreditasi ilmiah yang dikeluarkan oleh LIPI?

\section{Perumusan Masalah}

Berdasarkan latar belakang masalah, maka perumusan masalah dalam penelitian ini adalah bagaimana mutu Jurnal Perspektif Ilmu Pendidikan ditinjau dari Pedoman Akreditasi Majalah Ilmiah yang dikeluarkan oleh LIPI? dan indikator-indikator apa saja dalam Jurnal Perspektif Ilmu Pendidikan yang dirasakan masih kurang untuk mencapai berkala bermutu yang terakreditasi LIPI?

\section{Tujuan Penelitian}

Tujuan penelitian ini adalah untuk menggambarkan hasil evaluasi Jurnal Perspektif Ilmu Pendidikan berdasarkan pedoman akreditasi ilmiah yang dikeluarkan oleh LIPI.

\section{KAJIAN TEORETIS}

\section{Hakikat Jurnal Ilmiah}

\section{Pengertian Jurnal Ilmiah}

Jurnal adalah terbitan berkala yang berbentuk pamflet berseri berisi bahan yang sangat diminati orang saat diterbitkan. Bila dikaitkan dengan kata ilmiah di belakang kata jurnal, dapat berarti berkala yang berbentuk pamflet yang berisi bahan ilmiah yang sangat diminati orang saat diterbitkan (Direktorat
Jenderal Pendidikan Islam, 2008).

Dilihat dari segi akademik, jurnal ilmiah adalah publikasi yang dimaksudkan untuk memajukan kemajuan ilmu pengetahuan, biasanya dengan melaporkan penelitian baru. Jurnal ilmiah berisi artikel yang telah ditinjau, sebagai upaya untuk memastikan bahwa artikel jurnal memenuhi standar mutu dan validitas ilmiah. Setiap artikel jurnal ilmiah menjadi bagian dari catatan ilmiah yang sifatnya permanen (dictionary babylon, 2009).

Tulisan artikel dalam jurnal ilmiah adalah bahan yang sangat penting dalam penelitian. Artikel ilmiah dalam jurnal biasanya menyajikan isu-isu, teori-teori atau temuan-temuan terbaru tentang masalah-masalah tertentu di bidangnya. Selain itu, peneliti tentu juga dapat menemukan data terbaru dan/atau penafsiran kembali studi terdahulu (Zed, 2004: 12).

2. Jenis-Jenis Jurnal Ilmiah

Ada beberapa jenis penerbitan berkala, selain jurnal, yaitu majalah, bulletin, warkat warta. Majalah adalah terbitan berkala yang bukan harian, setiap keluar diberi halaman terpisah, biasanya diidentifikasi dengan tanggal dan bukan nomor berseri. Bulletin adalah berkala resmi yang dikeluarkan lembaga atau organisasi profesi ilmiah serta memuat berita, hasil dan laporan kegiatan dalam satu bidang. Warkat Warta, adalah terbitan pendek berisi berita, termasuk kemajuan keilmuan yang berisi catatan singkat yang mengutarakan materi secara umum dan tidak mendalam (Direktorat Jenderal Pendidikan Islam, 2008).

Selain itu, dari sisi teknis isi ada tiga macam berkala ilmiah yaitu 1) majalah teknis ilmiah, 2) berkala semi ilmiah, dan 3) berkala sekunder. Majalah teknis ilmiah merupakan majalah yang memuat hasil dan temuan baru penelitihan. Berkala ini biasanya sebagai sarana untuk komunikasi para pakar yang terspesialisasi (Direktorat Jenderal Pendidikan Islam, 2008).

Berkala semi ilmiah, yaitu berkala yang memuat tulisan teknis dengan cakupan yang bersifat ensiklopedia dan ditujukan bagi mereka yang bukan ahli atau spesialis dalam bidang yang dimaksud. Berkala sekunder berisi abstrak atau ringkasan majalah primer yang sering disebut pula berkala penyari (abstracting Jurnal). Selain itu, untuk keperluan pendidikan ada pula yang disebut berkala tinjauan yang memuat berbagai artikel ilmiah sejenis yang terbit beberapa tahun terakhir untuk memberikan gambaran kemajuan menyeluruh suatu topik. Berdasarkan pengertian, macam dan jenis tersebut di 
atas, di dalam pedoman ini dimaksudkan dengan jurnal ilmiah adalah terbitan berkala yang berisi kajian-kajian ilmiah yang spesifik dan dalam bidang tertentu (Direktorat Jenderal Pendidikan Islam, 2008). 3. Publikasi Jurnal Penelitian

Jurnal merupakan publikasi periodik untuk memperluas pengembangan sains, biasanya dengan melaporkan penelitian baru, yang berisi artikel yang telah di-peer-reviewed, untuk memenuhi standar kualitas jurnal dan kevalidan ilmu pengetahuan. Jurnal ini menyediakan pondasi bagi perkembangan ilmu pengetahuan, yaitu dalam komunikasi knowledge serta penyediaan rekam sejarah dan sumber dari pengetahuan terkini (Wikipedia, 2009). Publikasi dari hasil-hasil penelitian ini merupakan bagian penting dalam metode ilmiah.

Di bagian pengantar jurnal, dijabarkan dasar rasional dari pekerjaan penelitian untuk mencapai suatu set objektif tertentu serta review literature dari penelitian terkait. Jika publikasi tersebut menjabarkan eksperimen atau perhitungan, maka isi jurnal harus didukung dengan uraian detail sehingga peneliti independen dapat mengulang kembali eksperimen atau perhitungan untuk melakukan verifikasi hasil tersebut. Inilah yang membuat jurnal ini berbeda dengan artikel lain, yaitu bahwa di dalamnya tidak hanya berisi hasil penelitian, namun juga detail bagaimana hasil tersebut diperoleh. Di bagian diskusi, diisi hasil dan signifikansinya terhadap penelitian lain dalam satu area penelitian. Berikut ini dipaparkan alur penerbitan jurnal ilmiah, sebagai berikut.

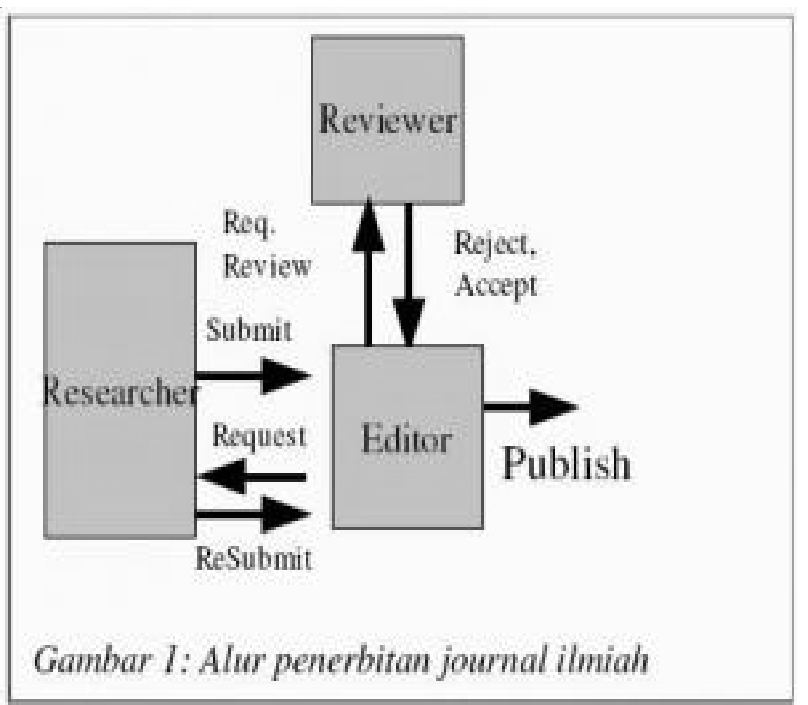

Sampai suatu penelitian dipublikasikan dalam jurnal akademis yang peer-reviewed, biasanya dilakukan dalam empat langkah (Gambar 1), yaitu: 1) peneliti mensubmit satu manuskrip artikel, 2) editor jurnal akan mengirimkan artikel tersebut ke setidaknya tiga reviewer yang terkualifikasi, 3) editor akan mengevaluasi hasil review dan menentukan apakah akan menolak atau menerima submission, 4) jika peneliti diminta untuk melakukan revisi, maka ia harus mensubmit kembali artikelnya (University of Brockport, 2009).

Terdapat enam kriteria yang diperlukan untuk membuat suatu jurnal, yaitu 1) objectivity, 2) replicability, 3) importance, 4) competence, 5) intelligibility, dan 6) efficiency. Kriteria (1) dan (2) membedakan paper scientific dari paper lain (Eko Didik Widianto, 2009).

Pertama, objectivity dapat didefinisikan bahwa suatu studi harus bebas dari bias peneliti. Ini merupakan kriteria utama dari pekerjaan ilmiah, sehingga pelanggaran terhadap kriteria ini harus mendapatkan perhatian yang serius dari peneliti. Bias ini dapat meliputi: bias terhadap peneliti dan bias terhadap bukti-bukti yang tidak dapat dikonfirmasi. Untuk mendapatkan objektivitas, dapat dilakukan dengan mensubmit jurnal dengan blind reviewer serta menggunakan hipotesis ganda (Eko Didik Widianto, 2009).

Kedua, replicability berarti bahwa peneliti lain dapat melakukan reproduksi elemen kunci dari penelitian ilmiah. Hal ini dapat juga berarti bahwa duplikasi beberapa elemen kunci dengan variasi elemen lain. Tujuan replikasi adalah untuk menentukan bahwa hasil yang sama dapat dihasilkan oleh peneliti lain. Dalam hal ini, peneliti harus menyediakan keterbukaan penuh tentang metode dan data dalam papernya dan dokumen pendukung lainnya (Eko Didik Widianto, 2009).

Ketiga, importance dalam jurnal bisa berarti, sebagai berikut.

1) Apakah masalahnya penting?

2) Apakah hasilnya menambah signifikansi bagi pengetahuan yang telah ada?

3) Apakah paper akan mempunyai pengaruh terhadap pengambilan keputusan atau riset berikutnya?

Kompetensi meliputi hal-hal berikut:

1) Apakah metode riset telah mencukupi?

2) Apakah paper telah benar dalam menggunakan riset sebelumnya

3) Apakah analisis yang dilakukan bebas dari error?

Keempat, intelligibility berarti bahwa jurnal ditulis dan didefinisikan dalam kalimat yang jelas, atau disebut juga readibility, karena fungsinya sebagai alat komunikasi pengetahuan. Sedangkan efisiensi berarti bahwa penggunaan kalimat dalam jurnal sesingkat mungkin (Eko Didik Widianto, 2009). 


\section{Hakikat Evaluasi}

\section{Pengertian Evaluasi}

Pemahaman mengenai pengertian evaluasi dapat berbeda-beda sesuai dengan pengertian evaluasi yang bervariatif oleh para pakar evaluasi. Pengertian evaluasi menurut Stufflebeam yang dikutip oleh yang dikutip oleh Ansyar (1989) bahwa evaluasi adalah proses memperoleh dan menyajikan informasi yang berguna untuk mempertimbangkan alternatif-alternatif pengambilan keputusan. Selanjutnya The joint committee on Standars For Educational Evaluation (1994), mendefinisikan bahwa evaluasi sebagai kegiatan investigasi yang sistematis tentang keberhasilan suatu tujuan.

Sedangkan Djaali, Mulyono dan Ramli (2000) (dalam Fuddin, 2008) mendefinisikan bahwa evaluasi sebagai proses menilai sesuatu berdasarkan standar objektif yang telah ditetapkan kemudian diambil keputusan atas obyek yang dievaluasi. Rutman and Mowbray 1983 (dalam Fuddin, 2008), mendefinisikan evaluasi adalah penggunaan metode ilmiah untuk menilai implementasi dan outcomes suatu program yang berguna untuk proses membuat keputusan.

Chelimsky (1989) (dalam Fuddin, 2008), mendefinisikan evaluasi adalah suatu metode penelitian yang sistematis untuk menilai rancangan, implementasi dan efektifitas suatu program. Wirawan (2006) (dalam Fuddin, 2008), evaluasi adalah proses mengumpulkan dan menyajikan informasi mengenai objek evaluasi, menilainya dengan standar evaluasi dan hasilnya dipergunakan untuk mengambil keputusan mengenai objek evaluasi.

Selain itu, Purwanto dan Suparman mengutip definisi yang dikembangkan oleh sebuah komisi evaluasi, menyebutkan bahwa evaluasi merupakan suatu pemeriksaan (penyelidikan yang sistematis) tentang manfaat atau kegunaan sesuatu berdasarkan standar tertentu (Purwanto dan Suparman, 1999: 3). Informasi-informasi yang diperoleh dalam evaluasi tersebut kemudian dijadikan sebagai acuan dalam menentukan apakah program atau media tersebut dapat terus digunakan, diproduksi, atau dihentikan.

Dari definisi evaluasi di atas dapat ditarik kesimpulan bahwa evaluasi adalah penerapan prosedur ilmiah yang sistematis untuk menilai rancangan, selanjutnya menyajikan informasi dalam rangka pengambilan keputusan terhadap implementasi dan efektifitas suatu program.

2. Jenis Evaluasi

Ada dua jenis evaluasi yang dikenal masyarakat, yaitu evaluasi formatif dan evaluasi sumatif. Kedua evaluasi tersebut dapat dibedakan dari waktu pelaksanaan dan fungsinya.

Evaluasi formatif dijelaskan sebagai pengawasan atau umpan balik yang berkelanjutan pada sebuah pelaksanaan program. Sedangkan, evaluasi sumatif melihat pada hasil akhir program (Neuman, 2003: 25). Menurut Stufflebeam, evaluasi formatif dipakai untuk perbaikan dan pengembangan kegiatan yang sedang berjalan (program, orang, produk, dan sebagainya). (Yusuf, 2000: 4).

Dalam kaitannya dengan media, evaluasi formatif bertujuan meningkatkan kualitas media yang sedang dikembangkan dengan mengumpulkan informasi mengenai media yang sedang dikembangkan apakah diperlukan modifikasi, atau revisi sebelum media selesai diproduksi. Tetapi, media yang dievaluasi bukan merupakan bentuk akhirnya (Kusumawati, 2009: 57).

Evaluasi sumatif berfungsi untuk memperoleh gambaran mengenai hasil yang telah dicapai pada akhir kegiatan, apakah program itu baik dan perlu digunakan terus atau perlu ditinggalkan (Kusumawati, 2009: 57). Evaluasi jenis ini ditujukan untuk melihat efektivitas dan efisiensi media dalam kegiatan pembelajaran sehingga dapat diambil keputusan oleh pemegang keputusan untuk terus menggunakan media tersebut, menghentikan penggunaan media, merevisi atau memodifikasi media.

Dalam penelitian ini, jenis evaluasi yang digunakan yaitu evaluasi formatif karena melihat pada perbaikan dan pengembangan Jurnal Perspektif Ilmu Pendidikan yang sedang berjalan.

\section{Aspek Evaluasi Jurnal Ilmiah Perspektif Ilmu Pendidikan}

Dalam mengevaluasi Jurnal Perspektif Ilmu Pendidikan yang akan dilakukan dalam penelitian ini maka ada beberapa aspek yang akan dievaluasi. Penentuan aspek yang akan dievaluasi sesuai dengan ketentuan yang dikeluarkan oleh Lembaga Ilmu Pengetahuan Indonesia berkaitan dengan Pedoman Akreditasi Majalah Ilmiah.

Sejak tahun 1975, Lembaga Ilmu Pengetahuan Indonesia telah melakukan penilaian terhadap terbitan (majalah) para peneliti lembaga penelitian atau pengembangan di Indonesia. Penilaian terhadap terbitan (majalah) ilmiah ini lebih ditekankan pada isi dan substansi terbitan, sehingga kriteria yang dinilaipun sebatas pada klasifikasinya yaitu bersifat ilmiah, semi ilmiah, populer serta campuran antara ketiganya. Pola penilaian ini dinilai kurang efektif karena bersifat sangat sederhana sehingga klasifikasi semacam ini tidak cukup berarti bagi pembangunan tradisi terbitan majalah ilmiah yang bermutu (LIPI, 
2009: 5).

Telah dilakukan langkah-langkah penyempurnaan pedoman instrumen evaluasi untuk akreditasi terbitan majalah ilmiah oleh Direktorat Jenderal Pendidikan Tinggi bekerja sama dengan Lembaga Ilmu Pengetahuan Indonesia, Ikatan Penyunting Indonesia dan Kantor Menteri Negara Riset dan Teknologi dengan tujuan untuk dijadikan acuan baik bagi peneliti maupun dosen. Akan tetapi karena lingkup penilaian LIPI masih pada klasifikasi, maka penilaian yang digunakan LIPI lebih kepada isi dan substansi dari pada keseluruhan sistematika pedoman penilaian (LIPI, 2009: 5).

Sehubungan dengan terbitnya Keputusan Menpan Nomor: KEP/128/M.PAN/9/2004 tentang jabatan peneliti dan Angka Kreditnya maupun Keputusan Bersama Kepala LIPI dengan Kepala BKN nomor 3719/D/2004 dan nomor: 60 tahun 2004, tentang Petunjuk Pelaksanaan jabatan Fungsional Peneliti dan Angka Kreditnya, mewajibkan LIPI sebagai Instansi pembina jabatan Fungsional Peneliti, melakukan akreditasi majalah ilmiah, maka dengan mengacu dan menyempurnakan konsep yang sudah ada sebelumnya LIPI, menyusun dan menetapkan Pedoman Akreditasi Majalah Ilmiah (LIPI, 2009: 5).

Digunakannya kata generik "majalah" dimaksudkan juga untuk segala macam bentuk, publikasi ilmiah lainnya tercetak maupun terekam pada CD ROM, DVD ROM, DVD/VCD, situs internet dan bentuk pengembangan media komunikasi lainnya.

\section{Penilaian Terbitan (Jurnal) Ilmiah}

Data-data tentang suatu terbitan berkala atau majalah ilmiah dipergunakan untuk menentukan mutu bentuk terbitannya. Data tersebut diperlukan karena merupakan kriteria yang dijadikan pedoman untuk menentukan peringkat dan status akreditasi suatu terbitan berkala ilmiah. Berbagai kriteria tersebut tidak memiliki nilai yang sama dalam kegiatan pengevaluasian, sehingga sesuai dengan makna dan kepentingannya, peringkat bobot yang diberikan kepada setiap kriteria yang berbeda-beda sebagai instrumen evaluasi yaitu.
Tabel 1. Kriteria Akreditasi Terbitan Berkala Ilmiah

\begin{tabular}{|c|l|c|}
\hline No & \multicolumn{1}{|c|}{ Unsur } & $\begin{array}{c}\text { Nilai } \\
\text { Tertinggi }\end{array}$ \\
\hline 1. & Nama berkala & 5 \\
\hline 2. & $\begin{array}{l}\text { Kelembagaan } \\
\text { Penerbit }\end{array}$ & 13 \\
\hline 3. & $\begin{array}{l}\text { Penyunting/De } \\
\text { wan Redaksi }\end{array}$ & 12 \\
\hline 4. & $\begin{array}{l}\text { Kemantapan } \\
\text { Penampilan }\end{array}$ & 9 \\
\hline 5. & Gaya Penulisan & $\mathbf{1 1}$ \\
\hline 6. & Substansi & 28 \\
\hline 7. & Keberkalaan & 10 \\
\hline 8. & Tiras & 5 \\
\hline 9. & Lain-lain & $\mathbf{1 0 0}$ \\
\hline & $\begin{array}{l}\text { Jumlah } \\
\text { Keseluruhan }\end{array}$ \\
\hline
\end{tabular}

\section{Cara Pemberian dan Penghitungan Nilai Terbitan (Jurnal) Ilmiah}

Untuk memudahkan pelaksanaan evaluasi, mutu serta peringkat akreditasi suatu terbitan ilmiah setiap kriteria dalam instrumen evaluasi dijabarkan menjadi beberapa butir. Berdasarkan data terbitan dan atau jilid, serta bersumber dari keterangan yang diberikan oleh pengelola suatu terbitan ilmiah, maka setiap butir kriteria tersebut oleh setiap terbitan ilmiah diberi nilai secara kuantitatif. Agar pengevaluasian dapat dilakukan dengan cepat, setiap kriteria disuguhkan seperangkat pilihan masing-masing dengan angka sudah diperhitungkan. Oleh karena itu, nilai skor yang diberikan atau diperoleh sudah merupakan angka mutlak untuk setiap butir kriteria. Pengelompokan nilai dan predikatnya adalah.

Tabel 2. Pengelompokan Nilai dan Predikat dari Terbitan Berkala Ilmiah

\begin{tabular}{|c|c|l|}
\hline Status & Nilai & \multicolumn{1}{|c|}{ Predikat } \\
\hline \multirow{4}{*}{$\begin{array}{c}\text { Tidak } \\
\text { Terakreditasi }\end{array}$} & $<30$ & Sangat buruk \\
\cline { 2 - 3 } & $30-39$ & Buruk \\
\cline { 2 - 3 } & $40-49$ & Sangat kurang \\
\cline { 2 - 3 } Terakreditasi & $50-59$ & Kurang \\
\cline { 2 - 3 } & $60-69$ & Cukup (C) \\
\cline { 2 - 3 } & $70-79$ & Baik (B) \\
\cline { 2 - 3 } & $80-100$ & Sangat baik (A) \\
\hline
\end{tabular}

Dengan demikian, nilai yang dapat diraih oleh setiap terbitan ilmiah untuk akreditasi adalah jumlah absolut nilai skor yang penghitunganya sudah ditentukan. Penetapan nilai yang dapat diperoleh suatu terbitan ilmiah menjadi terakreditasi sebagai berkala ilmiah jika sekurang-kurangnya memperoleh nilai cukup (C). 

memiliki syarat berikut.

\section{Pendekatan Penelitian}

Penelitian ini menggunakan pendekatan kuantitatif dengan pertimbangan bahwa penelitian ini menggunakan instrumen penelitian berupa indikator dan angka yang telah ditetapkan oleh LIPI di dalam Pedoman Akreditasi Majalah Ilmiah.

Penelitian kuantitatif adalah penelitian yang menggambarkan atau menjelaskan suatu masalah yang hasilnya dapat digeneralisasikan. Dengan demikian, tidak terlalu mementingkan kedalaman data atau analisis. Peneliti lebih mementingkan aspek keluasan data sehingga data atau hasil penelitian dianggap merupakan representasi dari seluruh populasi. Dalam penelitian kuantitatif, peneliti dituntut bersikap objektif dan memisahkan diri dari data (Kriyantono, 2007: 57).

Dalam penelitian kuantitatif, penelitian dilangsungkan mengikuti metode yang sudah disusun secara kaku, sehingga metode itu pulalah yang menentukan apa yang dapat diteliti, serta pengalaman (fenomena) apa yang dipelajari (Poerwandari, 2007: $35)$.

Oleh karena, peneliti harus menjaga sifat objektif maka dalam analisis datanya pun, peneliti tidak boleh mengikutsertakan analisis dan interpretasi yang bersifat subjektif. Oleh karena itu, digunakan uji statistik untuk menganalisis data (Kriyantono, 2007: 57).

\section{Metode penelitian}

Metode penelitian yang digunakan dalam penelitian ini yaitu analisis isi kuantitatif. Analisis isi kuantitatif adalah sebuah teknik untuk mengukur informasi atau isi dari lirik lagu, film, buku, dan lainlain (Neuman, 2003: 36). Hal yang sama turut dipaparkan oleh Wazer dan Wiener (Petra Christian University, 2005: 1), bahwa analisis isi adalah suatu prosedur sistematika yang disusun untuk menguji isi informasi yang terekam.

Ada beberapa konsep yang tercakup di dalam analisis isi kuantitatif. Pertama, analisis isi berarti isi yang dianalisis, dipilih menurut aturan yang diterapkan secara implisit, misalnya dengan cara menentukan sample. Kedua, analisis isi bersifat objektif yang artinya ada alat ukur yang ditentukan untuk menganalisis sample agar dapat meminimalkan unsur subjektifitas. Alat ukur tersebut berupa kategorisasi yang telah ditentukan sebelumnya. Dan yang ketiga, analisis isi bersifat kuantitatif yang artinya penghitungan serta hasil analisis dinyatakan dalam bentuk angka (Kriyantono, 2006: 228).
1. Data yang tersedia sebagian besar terdiri dari bahan-bahan yang terdokumentasi (buku, surat kabar, pita rekaman, naskah/manuscript, dan lainlain).

2. Ada keterangan pelengkap atau kerangka teori tertentu yang menerangkan tentang dan sebagai metode pendekatan terhadap data tersebut.

3. Peneliti memiliki kemampuan teknis untuk mengolah bahan-bahan/data-data yang dikumpulkannya karena sebagian dokumentasi tersebut bersifat sangat khas/spesifik (Yuris, 2009: 1).

Prosedur dasar pembuatan rancangan penelitian dan pelaksanaan studi analisis isi terdiri atas 6 tahapan langkah, yaitu (1) merumuskan pertanyaan penelitian dan hipotesisnya, (2) melakukan sampling terhadap sumber-sumber data yang telah dipilih, (3) pembuatan kategori yang dipergunakan dalam analisis, (4) pendataan suatu sampel dokumen yang telah dipilih dan melakukan pengkodean, (5) pembuatan skala dan item berdasarkan kriteria tertentu untuk pengumpulan data, dan (6) interpretasi/ penafsiran data yang diperoleh (Yuris, 2009: 1).

Urutan langkah tersebut harus tertib, tidak boleh dilompati atau dibalik. Langkah sebelumnya merupakan prasyarat untuk menentukan langkah berikutnya. Permulaan penelitian itu adalah adanya rumusan masalah atau pertanyaan penelitian yang dinyatakan secara jelas, eksplisit, dan mengarah, serta dapat diukur dan untuk dijawab dengan usaha penelitian.

Operasionalisasi konsep serta kategorisasi data dalam penelitian ini tidak dibuat oleh peneliti sendiri. Penelitian ini hanya menyesuaikan dengan operasionalisasi dan kategorisasi yang telah dibuat oleh LIPI dalam Pedoman Akreditasi Majalah Ilmiah sehingga pedoman tersebutlah yang dijadikan sebagai instrumen untuk melakukan analisis isi kuantitatif Jurnal Perspektif Ilmu Pendidikan.

\section{Populasi dan Sampel}

Populasi penelitian adalah seluruh edisi Jurnal Perspektif Ilmu Pendidikan dimulai dari tahun 20062008. Jumlah seluruh populasi penelitian yaitu enam buah karena Jurnal Perspektif Ilmu Pendidikan terbit dua kali dalam satu tahun yaitu setiap bulan April dan Oktober. Pengambilan sample dilakukan secara total sampling, di mana peneliti mengambil keseluruhan populasi sebagai sample karena jumlah populasi yang kecil yaitu hanya enam buah.

\section{Instrumen Penelitian}

Instrumen penilaian dalam penelitian ini 
dengan menggunakan lembar observasi yang berisi Pedoman Akreditasi Majalah Ilmiah. Lembar observasi terdiri atas berbagai indikator yang menjadi sebuah berkala ilmiah yang merupakan kriteria yang dapat dijadikan pedoman untuk menentukan peringkat dan status akreditasi suatu berkala ilmiah. Indikator yang bermacam-macam itu dengan sendirinya tidak memiliki nilai yang sama dalam kegiatan penilaian sehingga diperlukan pembobotan yang berbeda-beda agar diperoleh hasil yang objektif dan dapat dipertanggungjawabkan.

Nilai dan pembobotan tadi diukur berdasarkan dimensi fisik/penampilan, manajemen, dan substansi yang diperinci ke dalam berbagai aspek dengan bobotnya masing-masing, yaitu.

\section{Tabel 3. Kriteria Penilaian Akreditasi Terbitan} Berkala Ilmiah

\begin{tabular}{|c|l|c|}
\hline No & \multicolumn{1}{|c|}{ Unsur } & \multicolumn{1}{|c|}{$\begin{array}{c}\text { Nilai } \\
\text { Tertinggi }\end{array}$} \\
\hline 1. & Nama berkala & 5 \\
\hline 2. & $\begin{array}{l}\text { Kelembagaan } \\
\text { Penerbit }\end{array}$ & 13 \\
\hline 3. & $\begin{array}{l}\text { Penyunting/De } \\
\text { wan Redaksi }\end{array}$ & 12 \\
\hline 4. & $\begin{array}{l}\text { Kemantapan } \\
\text { Penampilan }\end{array}$ & 9 \\
\hline 5. & Gaya Penulisan & 11 \\
\hline 6. & Substansi & 28 \\
\hline 7. & Keberkalaan & 10 \\
\hline 8. & Tiras & 7 \\
\hline 9. & Lain-lain & $\mathbf{1 0 0}$ \\
\hline & $\begin{array}{l}\text { Jumlah } \\
\text { Keseluruhan }\end{array}$ & \\
\hline
\end{tabular}

Untuk memudahkan pelaksanaan penilaian, setiap aspek dalam instrumen penilaian dijabarkan menjadi beberapa variabel yang terdiri atas satu atau lebih indikator. Berdasarkan data yang dapat diambil langsung dari sejumlah nomor terbitan dan/atau jilid, serta bersumberkan keterangan yang diberikan oleh pengelola suatu berkala, dapatlah setiap butir indikator tadi diberi nilai secara kuantitatif. Agar penilaian dapat dilakukan dengan cepat, untuk setiap variabel disuguhkan seperangkat pilihan masingmasing dengan angka atau skor yang merupakan angka mutlak untuk setiap butir indikator.

Dengan demikian, skor yang dapat diraih suatu berkala untuk akreditasi adalah jumlah absolut skor, yang perhitungannya sudah dibobot. Suatu berkala menjadi terakreditasi jika sedikit-dikitnya memperoleh skor baik (>69).

\section{Teknik Analisis Data}

Data yang terkumpul melalui lembar observasi akan dianalisis secara deskriptif dengan kriteria panduan akreditasi berkala ilmiah dari LIPI tahun
2005. Adapun pengelompokan status, skor dan peringkatnya seperti tertera di bawah ini.

Tabel 4. Pengelompokan Status, Skor, dan Peringkat Terbitan Berkala Ilmiah

\begin{tabular}{|c|c|l|}
\hline Status & Nilai & \multicolumn{1}{|c|}{ Predikat } \\
\hline \multirow{4}{*}{$\begin{array}{c}\text { Tidak } \\
\text { terakreditasi }\end{array}$} & $<30$ & Sangat buruk \\
\cline { 2 - 3 } & $30-39$ & Buruk \\
\cline { 2 - 3 } & $40-49$ & Sangat kurang \\
\cline { 2 - 3 } Terakreditasi & $50-59$ & Kurang \\
\cline { 2 - 3 } & $60-69$ & Cukup (C) \\
\cline { 2 - 3 } & $70-79$ & Baik (B) \\
\cline { 2 - 3 } & $80-100$ & Sangat baik (A) \\
\hline
\end{tabular}

\section{Objek Penelitian}

Objek penelitian ini adalah Jurnal Perspektif Ilmu Pendidikan dengan identitas sebagai berikut. Judul : Jurnal Perspektif Ilmu Pendidikan

Penanggung Jawab : Dr. Karnadi, M.Si

Pemimpin Redaksi : Dr. Yuliani Nurani Sujiono, M.Pd

Sekretaris Redaksi $\quad$ : Prof. Dr. B.P. SitepuAlamat Redaksi : Kampus A UNJ, Gedung Daksinapati, Fakultas Ilmu Pendidikan, UNJ, Rawamangun, Jakarta Timur, 13220

$\begin{array}{ll}\text { Handphone } & : 081387754965 \\ \text { ISSN } & : 1411-5255\end{array}$

\section{HASIL PENELITIAN}

\section{Deskripsi Data Evaluasi Mutu Jurnal Perspektif Ilmu Pendidikan}

\section{Nama Berkala}

Perspektif Ilmu Pendidikan merupakan nama jurnal yang singkat sehingga mudah diacu. Nama Jurnal Perspektif Ilmu Pendidikan yang dipakai menonjolkan bidang ilmu dan/atau bidang aplikasi dan bukan nama lembaga/organisasi atau kota penerbitnya sehingga nilai skor yang bisa diberikan untuk Jurnal Perspektif Ilmu Pendidikan sesuai dengan unsur nama berkala yang telah diterbitkan oleh LIPI, sebagai berikut.

Tabel 5. Hasil Penghitungan Aspek Nama Berkala Jurnal Perspektif Ilmu Pendidikan

\begin{tabular}{|l|c|}
\hline \multicolumn{1}{|c|}{$\begin{array}{c}\text { Nama } \\
\text { Berkala }\end{array}$} & $\begin{array}{c}\text { Nilai } \\
\text { Skor }\end{array}$ \\
\hline $\begin{array}{l}\text { Kesesuaian } \\
\text { nama }\end{array}$ & \\
\hline $\begin{array}{l}\text { Sangat } \\
\text { spesifik dan } \\
\text { sesuai } \\
\text { dengan } \\
\text { spesialisasi } \\
\text { bidang } \\
\text { ilmu/aplikasi }\end{array}$ & 5 \\
\hline \multicolumn{1}{|l|}{ JUMLAH } & \\
\hline
\end{tabular}




\section{Kelembagaan Penerbit}

Lembaga penerbit dari Jurnal Perspektif Ilmu Pendidikan adalah Fakultas Ilmu Pendidikan yang merupakan badan hukum dan mampu memberikan jaminan kesinambungan dana dan naungan hukum. Pengelolaan penerbit Jurnal Perspektif Ilmu Pendidikan merupakan bagian dari Fakultas Ilmu Pendidikan. Selain itu, kegiatan penerbitan mengikuti pembakuan nasional, hal ini dibuktikan dari adanya ISSN pada Jurnal Perspektif Ilmu Pendidikan.

Nilai skor yang bisa diberikan untuk Jurnal Perspektif Ilmu Pendidikan sesuai dengan unsur kelembagaan penerbit yang telah diterbitkan oleh LIPI, sebagai berikut.

Tabel 6. Hasil Penghitungan Aspek Kelembagaan Penerbit Jurnal Perspektif Ilmu Pendidikan

\begin{tabular}{|c|c|}
\hline \multicolumn{1}{|c|}{$\begin{array}{c}\text { Kelembagaan } \\
\text { Penerbit }\end{array}$} & $\begin{array}{c}\text { Nilai } \\
\text { Skor }\end{array}$ \\
\hline $\begin{array}{l}\text { 1. Pranata penerbit } \\
\text { Satuan organisasi teknis il- } \\
\text { miah berbadan hukum, } \\
\text { misal lembaga penelitian } \\
\text { setingkat pusat/lembaga } \\
\text { eselon II atau lebih tinggi } \\
\text { yang disesuaikan dengan } \\
\text { kondisi setempat, pergu- } \\
\text { ruan tinggi setingkat fakul- } \\
\text { tas atau lebih tinggi serta } \\
\text { organisasi profesi ilmiah. }\end{array}$ & 5 \\
\hline $\begin{array}{l}\text { 2. Pengelolaan penerbit } \\
\text { Bagian dari lembaga induk }\end{array}$ & 2 \\
\hline $\begin{array}{l}\text { 3. Landasan/Pembakuan } \\
\text { Nasional/Internasional }\end{array}$ & 4 \\
Ada ISSN & 11 \\
\hline \multicolumn{2}{|c|}{ JUMLAH } \\
\hline
\end{tabular}

\section{Penyunting/Dewan Redaksi/Editor}

1) Penyuntingan dituntut melibatkan mitra bestari (peer group) dari lingkungan luas sebagai penelaah ahli.

2) Peyunting/Dewan Redaksi/Editor bertugas untuk menilai dan mengkaji kandungan ilmiah suatu karya tulis ilmiah.

3) Para penyunting/Editor hendaklah terdiri atas perorangan berkualifikasi dan berpengalaman yang mempunyai waktu, kemauan, kemampuan, dan komitmen untuk melaksanakan penyuntingan suatu karya ilmiah.

4) Pengangkatan resmi sebagai anggota sidang penyunting/ editor dilakukan bukan karena jabatan struktural ex officio tetapi karena kualifikasi kepakaran seseorang.

5) Penggarisan tugas (misalnya penyunting penyelia, penyunting pelaksana, penyunting tamu) dinyatakan secara tegas dan gamblang.

6) Cakupan mandat bidang keilmuan agar lengkap terwakili oleh anggota sidang penyunting/editor

Berikut ini, nilai atau skor yang bisa diberikan untuk Jurnal Perspektif Ilmu Pendidikan sesuai dengan unsur Penyunting/Dewan Redaksi/Editor yang telah diterbitkan oleh LIPI, sebagai berikut.

Tabel 7. Hasil Penghitungan Aspek Penyunting/

Dewan Redaksi/Editor Jurnal Perspektif Ilmu Pendidikan

\begin{tabular}{|c|c|}
\hline $\begin{array}{c}\text { Penyunting/Dewan } \\
\text { Redaksi/Editor }\end{array}$ & $\begin{array}{l}\text { Nilai } \\
\text { Skor }\end{array}$ \\
\hline $\begin{array}{l}\text { 1. Pelibatan mitra bestari } \\
\text { sebagai penelaah ahli } \\
\text { Pakar (Peneliti Utama, } \\
\text { guru besar atau yang } \\
\text { setingkat) dalam negeri } \\
\text { lingkungan setempat }\end{array}$ & 3 \\
\hline $\begin{array}{l}\text { 2. Kualifikasi penyunting } \\
\text { Lebih dari } 50 \% \text { terdiri } \\
\text { dari Peneliti } \\
\text { Utama/lektor kepala } \\
\text { dan/atau ahli } \\
\text { peneliti/guru besar } \\
\text { dan/atau berpendidikan } \\
\text { S2 dan S3 yang setingkat }\end{array}$ & 2 \\
\hline $\begin{array}{l}\text { 3. Keterlibatan pejabat } \\
\text { struktural dalam } \\
\text { kompetensi penyunting } \\
\text { Tidak ada }\end{array}$ & 2 \\
\hline $\begin{array}{l}\text { 4. Keperwakilan pakar } \\
\text { bidang ilmu dalam } \\
\text { komposisi penyunting } \\
\text { Cukup }\end{array}$ & 1 \\
\hline $\begin{array}{l}\text { 5. Penggarisan tugas } \\
\text { masing-masing } \\
\text { penyunting, } \\
\text { pembedaan antara } \\
\text { penyunting penyelia, } \\
\text { penyunting pelaksana } \\
\text { dan penyunting tamu } \\
\text { Ada dan berfungsi }\end{array}$ & 2 \\
\hline JUMLAH & 10 \\
\hline
\end{tabular}

Dalam Jurnal Perspektif Ilmu Pendidikan, naskah-naskah yang masuk belum melibatkan mitra bestari (peer group) dari lingkungan luas sebagai penelaah ahli, meskipun di dalam jurnal dicantumkan ada sembilan penyunting ahli atau mitra bestari yang terdiri dari enam mitra bestari dari dalam lingkungan 
FIP UNJ sedangkan tiga mitra bestari dari Universitas Negeri Padang, Unila, dan Universitas Bengkulu. Peranan mitra bestari dalam Jurnal Perspektif Ilmu Pendidikan diperlukan untuk menentukan kelayakan sebuah naskah bisa atau tidaknya masuk ke dalam sebuah jurnal.

Editor dari Jurnal Perspektif Ilmu Pendidikan bertugas untuk menilai dan mengkaji kandungan ilmiah suatu karya tulis ilmiah dilihat dari substansi isi naskah maupun penggunaan EYD dalam naskah tersebut. Para penyunting/editor dari Jurnal Perspektif Ilmu Pendidikan terdiri atas perorangan yang berkualifikasi dan berpengalaman serta mempunyai waktu, kemauan, kemampuan, dan komitmen untuk melaksanakan penyuntingan suatu karya ilmiah.

Pengangkatan resmi sebagai editor dilakukan karena kualifikasi kepakarannya, hal ini bisa dilihat dari curriculum vitae dewan editor yang ada di lampiran 2. Dalam Jurnal Perspektif Ilmu Pendidikan, setiap dewan editor ketika menilai atau mengkaji sebuah karya tulis ilmiah selalu diberikan petunjuk editing editor. Petunjuk editing editor memberikan kemudahan kepada para editor untuk melihat aspek atau indikatorindikator apa saja yang perlu dinilai dalam sebuah karya tulis ilmiah.

\section{Kemantapan Penampilan}

Berikut ini adalah hal-hal yang dilihat dari unsur kemantapan penampilan, yaitu.

1. Konsistensi ukuran, tata letak, tipe huruf, jenis kertas, jumlah halaman per penerbitan dan lainlainnya.

2. Penampilan umum berkala agar memiliki tanda kenal yang cukup memikat (eye catching) sehingga menonjol jika tersimpan dalam meja pajangan kumpulan majalah yang baru datang.

3. Pencantuman nomor akreditasi dan masa berlaku akreditasi pada setiap penerbitan.

4. Sebagai panduan untuk menjadikan suatu berkala ilmiah mempunyai penampilan baik, dapat digunakan buku terbitan PDII-LIPI: Pedoman Penampilan Majalah Ilmiah Indonesia

Nilai atau skor yang bisa diberikan untuk Jurnal Perspektif Ilmu Pendidikan sesuai dengan unsur kemantapan penampilan yang telah diterbitkan oleh LIPI, sebagai berikut.
Tabel 8. Hasil Penghitungan Aspek Kemantapan Penampilan Jurnal Perspektif Ilmu Pendidikan

\begin{tabular}{|c|c|}
\hline $\begin{array}{l}\text { Kemantapan } \\
\text { Penampilan }\end{array}$ & $\begin{array}{l}\text { Nilai } \\
\text { Skor }\end{array}$ \\
\hline $\begin{array}{l}\text { 1. Ukuran berkala } \\
\text { Mantap/baku }\end{array}$ & 1 \\
\hline $\begin{array}{l}\text { 2. Tata letak } \\
\text { Mantap/bagus } \\
\text { dan baku }\end{array}$ & 1 \\
\hline $\begin{array}{l}\text { 3. Tipe huruf } \\
\text { Mantap/konsisten }\end{array}$ & 1 \\
\hline $\begin{array}{l}\text { 4. Jenis kertas } \\
\text { Mantap/bagus }\end{array}$ & 1 \\
\hline $\begin{array}{l}\text { 5. Konsistensi } \\
\text { jumlah halaman } \\
\text { per penerbitan } \\
\text { Selisih tidak } \\
\text { melebihi } 25 \%\end{array}$ & 1 \\
\hline $\begin{array}{l}\text { 6. Warna sampul } \\
\text { Mantap/bagus }\end{array}$ & 1 \\
\hline $\begin{array}{l}\text { 7. Berpenciri } \\
\text { terkenali dari } \\
\text { jauh } \\
\text { Ya } \\
\end{array}$ & 1 \\
\hline $\begin{array}{l}\text { 8. Rancangan } \\
\text { memikat } \\
\text { Ya }\end{array}$ & 1 \\
\hline $\begin{array}{l}\text { 9. Kesan untuk } \\
\text { Kemantapan } \\
\text { Terpelihara }\end{array}$ & 1 \\
\hline JUMLAH & 9 \\
\hline
\end{tabular}

Jurnal Perspektif Ilmu Pendidikan untuk setiap edisinya memiliki ukuran yang tetap dilihat dari tata letak menggunakan page maker 7.0, tipe huruf yaitu book antiqua dengan ukuran huruf 10 , jenis kertas yaitu HVS A-4 80 gram, dan jumlah halaman untuk setiap edisi Jurnal Perspektif Ilmu Pendidikan yaitu lebih kurang 100 halaman dengan selisih halaman setiap edisi kurang dari $25 \%$. Rinciannya, sebagai berikut.

1. Jurnal Perspektif Ilmu Pendidikan edisi vol. $14 \mathrm{Th}$. VII Oktober 2006 sebanyak 102 halaman

2. Jurnal Perspektif Ilmu Pendidikan edisi vol. $15 \mathrm{Th}$. VIII April 2007 sebanyak 100 halaman

3. Jurnal Perspektif Ilmu Pendidikan edisi vol. 16 Th. VIII Oktober 2007 sebanyak 120 halaman

4. Jurnal Perspektif Ilmu Pendidikan edisi vol. 17 Th. IX April 2008 sebanyak 100 halaman

5. Jurnal Perspektif Ilmu Pendidikan edisi vol. $18 \mathrm{Th}$. X Oktober 2008 sebanyak 108 halaman

6. Jurnal Perspektif Ilmu Pendidikan edisi khusus tahun 2009 sebanyak 100 halaman

7. Perspektif Ilmu Pendidikan edisi vol. 19 Th. XI April 2009 sebanyak 102 halaman

Warna sampul untuk setiap edisi berbeda-beda dan tidak pernah ada warna sampul yang sama. Jurnal Perspektif Ilmu Pendidikan memiliki ciri pada tulisan maupun logonya. Tulisan Perspektif Ilmu Pendidikan ditulis dengan tinta hijau disertai dengan tulisan di 
bawah Perspektif Ilmu Pendidikan yang bertuliskan ilmu pendidikan juga dengan warna hijau. Logo pun ditampilkan dalam sampul jurnal dengan warna hijau.

\section{Gaya Penulisan}

1. Kemantapan tata cara penyajian (sistematika, pembaban, pengadaan abstrak dan kata kunci), penyuguhan (gaya, sistem pengacuan pustaka, daftar kepustakaan), penyuguhan pelengkap dan pendukung (seperti gambar, foto, tabel, grafik dan catatan kaki) serta ketaat-asasan pada gaya selingkung biasa dipakai pada bidang ilmu dan atau bidang aplikasi yang bersangkutan, mutlak wajib di pertahankan

2. Kemapanan pencantuman nama-nama penulis (tanpa gelar akademis) dan alamat lembaga tempat kegiatan penelitian supaya dilakukan secara bertaat asas.

3. Pencantuman petunjuk yang jelas bagi penulis dalam setiap penerbitan.

4. Pembacaan contoh cetak oleh penulis sebagai kendali gaya penulisan seyogyanya diselenggarakan.

Berikut ini adalah nilai skor yang diberikan kepada Jurnal Perspektif Ilmu Pendidikan untuk unsur gaya penulisan berdasarkan pedoman akreditasi majalah ilmiah LIPI.

Tabel 9. Hasil Penghitungan Aspek Gaya Penulisan Jurnal Perspektif Ilmu Pendidikan

\begin{tabular}{|l|c|}
\hline \multicolumn{1}{|c|}{ Gaya Penulisan } & $\begin{array}{c}\text { Nilai } \\
\text { Skor }\end{array}$ \\
\hline $\begin{array}{l}\text { 1. Sistematika penulisan } \\
\text { Lengkap }\end{array}$ & 2 \\
\hline $\begin{array}{l}\text { 2. } \text { Konsistensi pembaban } \\
\text { Ya }\end{array}$ & 1 \\
\hline $\begin{array}{l}\text { 3. Abstrak } \\
\text { Ada }\end{array}$ & 1 \\
\hline $\begin{array}{l}\text { 4. } \text { Kata kunci } \\
\text { Ada }\end{array}$ & 1 \\
\hline $\begin{array}{l}\text { 5. Penyajian instrumen } \\
\text { pendukung, gambar (catatan } \\
\text { kaki, grafik, bagan, tabel dst.) } \\
\text { Informatif dan } \\
\text { komplementer }\end{array}$ & 1 \\
\hline $\begin{array}{l}\text { 6. Cara pengacuan dan pengutipan } \\
\text { Baku }\end{array}$ & 1 \\
\hline $\begin{array}{l}\text { 7. Penyusunan daftar pustaka } \\
\text { Baku/Konsisten }\end{array}$ & 1 \\
\hline $\begin{array}{l}\text { 8. Pencantuman nama penulis dan } \\
\text { nama lembaga } \\
\text { Baku/Konsisten }\end{array}$ & 1 \\
\hline $\begin{array}{l}\text { 9. Petunjuk bagi calon penulis } \\
\text { dalam setiap penerbitan } \\
\text { Lengkap }\end{array}$ & 1 \\
\hline $\begin{array}{l}\text { 10.Pembacaan contoh cetak oleh } \\
\text { penulis } \\
\text { Tidak }\end{array}$ & 0 \\
\hline & 10 \\
\hline
\end{tabular}

Tabel di atas menjelaskan untuk sistematika penulisan, Jurnal Perspektif Ilmu Pendidikan sudah bisa dikatakan lengkap karena setiap artikel ilmiahnya apabila merupakan penelitian maka memuat empat hal yaitu pendahuluan, kajian teoretis, metodologi penelitian, hasil penelitian, kesimpulan, daftar pustaka, dan keterangan penulis. Sedangkan jika opini, sistematika penulisannya adalah pendahuluan, pembahasan, dan kesimpulan. Semua pembaban dari setiap edisi Jurnal Perspektif Ilmu Pendidikan memiliki kekonsistenan sesuai dengan sistematika penulisan.

Abstrak dan kata kunci dalam Jurnal Perspektif Ilmu Pendidikan dimuat pada halaman pertama dan berbahasa Inggris. Bagan, diagram, dan gambar dalam Jurnal Perspektif Ilmu Pendidikan diberi nomor urut berdasarkan angka arab, dengan diberi judul singkat menggunakan huruf kapital serta diberi nama mendatar. Teks penamaan harus jelas dan sesuai dengan yang diperlihatkan pada gambar dan tiap gambar harus disajikan pada kertas terpisah dan dapat direproduksi. Tabel harus diberi nomor urut dengan menggunakan angka arab dan deskripstif judul tabel dibuat sesingkat mungkin serta diberi nama ke bawah dan ke samping.

Cara pengacuan atau pengutipan yang digunakan oleh Jurnal Perspektif Ilmu Pendidikan diberlakukan secara konsisten dengan mencantumkan nama belakang pengarang, tahun, dan nomor halaman. Penyusunan daftar pustaka mengadopsi sistem APA (American Psychological Association).

Di setiap akhir artikel yang ada dalam Jurnal Perspektif Ilmu Pendidikan selalu memberikan keterangan mengenai biografi penulis. Nama penulis tidak diberi gelar. Namun, tidak memuat alamat tempat penelitian itu berlangsung, yang ada hanya nama penulis tanpa gelar, tempat tanggal lahir, dan instansi tempat kerja dari penulis.

Calon-calon penulis yang ingin memasukkan artikelnya ke Jurnal Perspektif Ilmu Pendidikan bisa melihat petunjuk penulisan jurnal di setiap akhir halaman jurnal pada setiap penerbitannya sehingga bagi calon penulis yang ingin memasukkan naskah jurnal bisa membacanya. Pembacaan contoh cetak oleh penulis selama ini belum dilakukan, penulis hanya diberikan hasil jurnal yang sudah jadi dan dicover dengan rapih.

\section{Substansi}

1. Berisi hasil-hasil penelitian ilmiah, dan/atau konsep ilmiah dari disiplin ilmu pengetahuan dan teknologi tertentu.

2. Publikasi ditujukan kepada masyarakat ilmiah/ peneliti, yang mempunyai disiplin keilmuan yang 
relevan.

3. Cakupan bidang keilmuan keseluruhan majalah merupakan indikator yang penting, dengan catatan bahwa makin berspesialisasi makin tinggi nilainya.

4. Sumbangan majalah pada kemajuan ilmu dan teknologi, diukur dari derajat keorisinalan tulisan yang dimuat, menentukan posisi majalah dalam percaturan pengembangan dan penguasaan ilmu.

5. Bobot pustaka acuan ditentukan dengan melihat perbandingan kadar sumber primer, serta kemutakhiran bahan yang diacu dengan melihat proporsi terbitan 10 tahun terakhir, merupakan tolok ukur mutu berkala ilmiah yang penting. Keseringan mengacu pada diri sendiri (self-citation) mengurangi nilai.

6. Analisis, sintesis, dan penyimpulan, serta perampatan dan pencetusan teori baru yang secara mapan dituangkan dalam tulisan-tulisan yang dimuat akan meningkatkan martabat berkala ilmiah.

7. Dampak ilmiah antara lain diukur dari keseringan diacu, kemampuan berfungsi sebagai sumber ilmiah, dan wibawa temuan, merupakan parameter penentu mutu berkala yang penting.

8. Keuniversalan lebih penting dibandingkan kenasionalan, apalagi kelokalan

Berikut ini adalah nilai skor yang diberikan kepada Jurnal Perspektif Ilmu Pendidikan untuk unsur gaya penulisan berdasarkan pedoman akreditasi majalah ilmiah LIPI.

Tabel 10. Hasil Penghitungan Aspek Substansi Jurnal Perspektif Ilmu Pendidikan

\begin{tabular}{|c|c|}
\hline Gaya Penulisan & $\begin{array}{l}\text { Nilai } \\
\text { Skor }\end{array}$ \\
\hline $\begin{array}{l}\text { 1. Sistematika penulisan } \\
\text { Lengkap }\end{array}$ & 2 \\
\hline $\begin{array}{l}\text { 2. Konsistensi pembaban } \\
\mathrm{Ya}\end{array}$ & 1 \\
\hline $\begin{array}{l}\text { 3. Abstrak } \\
\text { Ada }\end{array}$ & 1 \\
\hline $\begin{array}{l}\text { 4. Kata kunci } \\
\text { Ada }\end{array}$ & 1 \\
\hline $\begin{array}{l}\text { 5. Penyajian instrumen pendukung, } \\
\text { gambar (catatan kaki, grafik, bagan, } \\
\text { tabel dst.) } \\
\text { Informatif dan } \\
\text { komplementer }\end{array}$ & 1 \\
\hline $\begin{array}{l}\text { 6. Cara pengacuan dan pengutipan } \\
\text { Baku }\end{array}$ & 1 \\
\hline $\begin{array}{l}\text { 7. Penyusunan daftar pustaka } \\
\text { Baku/Konsisten }\end{array}$ & 1 \\
\hline $\begin{array}{l}\text { 8. Pencantuman nama penulis dan nama } \\
\text { lembaga } \\
\text { Baku/Konsisten }\end{array}$ & 1 \\
\hline $\begin{array}{l}\text { 9. Petunjuk bagi calon penulis dalam } \\
\text { setiap penerbitan } \\
\text { Lengkap }\end{array}$ & 1 \\
\hline $\begin{array}{l}\text { 10.Pembacaan contoh cetak oleh penulis } \\
\text { Tidak }\end{array}$ & 0 \\
\hline JUMLAH & 10 \\
\hline
\end{tabular}

\section{Keberkalaan}

1. Ketaatan periode frekuensi penerbitan harus sesuai dengan jadwal yang ditentukan, dan/atau sesuai dengan nama yang disandang majalah. Perlu dicatat bahwa penerbitan tidak teratur (irregular) merupakan ukuran keberkalaan yang diperkenankan, asal tegas dikatakan.

2. Kemantapan tata penomoran perlu dijaga sesuai dengan keberkalaan dengan mencantumkan nomor, volume (dapat dengan angka arab) dan nomor bagian (umumnya dengan angka arab) yang tidak bergantung pada tahun terbit.

3. Penomoran halaman yang berkesinambungan dari 1-n dalam suatu jilid yang belum ditutup dengan indeks isi, dan bukan mulai lagi dari halaman 1 untuk setiap nomor bagian yang terbit, merupakan indikator keberkalaan yang baik.

4. Indeks penutup volume sebagai pertanda dilakukannya kendali keberkalaan supaya diadakan.

5. Ketersediaan dana dan naskah berkelanjutan adalah salah satu ukuran jaminan keberkalaan.

Berikut ini adalah nilai skor yang diberikan kepada Jurnal Perspektif Ilmu Pendidikan untuk unsur keberkalaan berdasarkan pedoman akreditasi majalah ilmiah LIPI.

Tabel 11. Hasil Penghitungan Aspek Keberkalaan Jurnal Perspektif Ilmu Pendidikan

\begin{tabular}{|l|c|}
\hline Keberkalaan & $\begin{array}{c}\text { Nilai } \\
\text { Skor }\end{array}$ \\
\hline $\begin{array}{l}\text { 1. } \\
\text { Frekuensi } \\
\text { penerbitan } \\
\text { Sesuai } \\
\text { dengan } \\
\text { jadwal yang } \\
\text { ditentukan }\end{array}$ & 2 \\
\hline $\begin{array}{l}\text { Tata } \\
\text { penomoran } \\
\text { majalah } \\
\text { Konsisten }\end{array}$ & 2 \\
\hline $\begin{array}{l}\text { Penomoran } \\
\text { halaman } \\
\text { Tiap nomor } \\
\text { dimulai } \\
\text { dengan } \\
\text { halaman 1 }\end{array}$ & 0 \\
\hline $\begin{array}{l}\text { Indeks tiap } \\
\text { jilid } \\
\text { Tidak ada }\end{array}$ & 0 \\
\hline $\begin{array}{l}\text { 5. } \\
\text { Sumber dana } \\
\text { Terjamin } \\
\text { dengan } \\
\text { teratur }\end{array}$ & 2 \\
\hline $\begin{array}{l}\text { Ketersediaan } \\
\text { naskah } \\
\text { 1oo\% isi satu } \\
\text { nomor }\end{array}$ & 1 \\
\hline JuMLAH & 7 \\
\hline
\end{tabular}


Frekuensi penerbitan Jurnal Perspektif Ilmu Pendidikan dilaksanakan setiap setahun dua kali yaitu terbit setiap bulan April dan Oktober. Tata penomoran Jurnal Perspektif Ilmu Pendidikan dilakukan secara berurutan dimulai dari volume dan tahun ke berapa sudah terbit. Penomoran halaman dalam sebuah jurnal hendaknya dimulai dari halaman 1 dan berkesinambungan ke volume berikutnya dengan catatan bahwa jurnal tersebut dalam tahun terbit yang sama. Misal, suatu jurnal volume 1 no. 1 terbit bulan Januari 2009 dimulai dari halaman 1 dan berakhir halaman 100 kemudian untuk jurnal volume 1 no. 2, halaman akan dimulai dari 101 hingga 202. Sedangkan, dalam Jurnal Perspektif Ilmu Pendidikan, nomor halaman selalu dimulai dengan halaman 1 .

Jurnal Perspektif Ilmu Pendidikan tidak memiliki indeks di tiap edisinya. Sumber pendanaan Jurnal Perspektif Ilmu Pendidikan terjamin dengan teratur oleh Fakultas Ilmu Pendidikan. Dalam setiap edisinya, Jurnal Perspektif Ilmu Pendidikan memiliki ketersediaan yang mencukupi untuk satu edisi sekalipun ada naskah-naskah yang lain jumlahnya tidak terlampau banyak untuk isi satu edisi berikutnya.

\section{Tiras}

1. Berkala ilmiah harus dicetak (bukan distensil ataupun difotokopi) minimum 300 eksemplar, dengan syarat 150 tersebar langsung melalui langganan atau pertukaran tetap.

2. Berkala hendaklah memberikan cetak lepas (reprint, offprint) kepada setiap penulis untuk memperluas keterjangkauan.

3. Peraturan wajib simpan mutlak harus ditaati. Ketersediaan berkala dalam perpustakaan utama merupakan salah satu pengukur keluasan persebaran.

Berikut ini adalah nilai skor yang diberikan kepada Jurnal Perspektif Ilmu Pendidikan untuk unsur tiras berdasarkan pedoman akreditasi majalah ilmiah LIPI.

Tabel 12. Hasil Penghitungan Aspek Tiras Jurnal Perspektif Ilmu Pendidikan

\begin{tabular}{|l|c|}
\hline \multicolumn{1}{|c|}{ Tiras } & $\begin{array}{c}\text { Nilai } \\
\text { Skor }\end{array}$ \\
\hline 1. $\begin{array}{l}\text { Tiras } \\
\text { minimum } \\
\text { terpenuhi } \\
\text { Tidak }\end{array}$ & 1 \\
\hline 2. $\begin{array}{l}\text { Menyediakan } \\
\text { cetak lepas } \\
\text { Tidak }\end{array}$ & O \\
\hline 3. $\begin{array}{l}\text { Menmenuhi } \\
\text { Wajib simpan } \\
\text { (di PDII LIPI) } \\
\text { Ya }\end{array}$ & 1 \\
\hline
\end{tabular}

Jurnal Perspektif Ilmu Pendidikan dicetak sebanyak 100 halaman atau tidak memenuhi batas minimum yang ditetapkan oleh LIPI sebanyak 300 eksemplar. Jurnal Perspektif Ilmu Pendidikan tidak pernah memberikan cetak lepas kepada setiap penulis. Cetak lepas yaitu hasil cetak jurnal yang sudah dilayout yang hanya berisi tulisan satu orang penulis. Peraturan wajib simpan di LIPI dilakukan oleh Jurnal Perspektif Ilmu Pendidikan.

\section{Lain-lain}

Butir-butir yang diperkenankan

1. Iklan dapat dimuat asal dicantumkan dalam halaman berpenomoran khusus yang tidak mengganggu kesinambungan penomoran halaman jilid, dan harus terpisah sehingga bisa dibuang dalam proses penjilidan.

2. Artikel ulasan dan tinjauan atas undangan dapat dipertimbangkan pemuatannya, bahkan dianjurkan untuk terbitan oleh organisasi profesi sebagai penampung pertanggungjawaban ilmiah ketua perhimpunan.

3. Rubrik tinjauan buku baru dianjurkan diadakan.

4. Pemuatan obituari (berita atas seseorang yang baru meninggal) tokoh ilmuwan dalam bidang cakupan majalah sangat dianjurkan.

\section{Butir-butir yang tidak boleh ada}

1. Foto penulis artikel, kecuali ketua organisasi profesi ilmiah yang membacakan orasi pertanggungjawaban ilmiah atas undangan.

2. Berita keluarga, berita organisasi, berita peristiwa keilmuan.

Berikut ini adalah nilai skor yang diberikan kepada Jurnal Perspektif Ilmu Pendidikan untuk unsur lain-lain berdasarkan pedoman akreditasi majalah ilmiah LIPI.

Tabel 13. Hasil Penghitungan Aspek Lain-lain Jurnal Perspektif Ilmu Pendidikan

\begin{tabular}{|l|c|}
\hline \multicolumn{1}{|c|}{ Lain-lain } & \multicolumn{1}{|c|}{$\begin{array}{c}\text { Nilai } \\
\text { Skor }\end{array}$} \\
\hline 1. $\begin{array}{l}\text { Penyediaan halaman } \\
\text { khusus untuk iklan } \\
\text { Tidak ada iklan }\end{array}$ & 2 \\
\hline 2. $\begin{array}{l}\text { Pemuatan artikel ulasan } \\
\text { dan tinjauan ilmiah atas } \\
\text { undangan } \\
\text { Tidak }\end{array}$ & $\mathrm{O}$ \\
\hline 3. $\begin{array}{l}\text { Pemuatan tinjauan buku } \\
\text { ilmiah baru yang sesuai } \\
\text { dengan bidang keilmuan } \\
\text { berkala } \\
\text { Tidak }\end{array}$ & 0 \\
\hline $\begin{array}{l}\text { 4. Pemuatan obituari tokoh } \\
\text { ilmuan dalam bidang } \\
\text { yang sesuai dengan } \\
\text { bidang keilmuan berkala } \\
\text { Tidak }\end{array}$ & 0 \\
\hline 5. Pemuatan foto penulis \\
artikel \\
Tidak
\end{tabular}


Tidak ada penyediaan halaman khusus untuk iklan, artikel ulasan dan tinjauan atas undangan, pemuatan obituari (berita atas seseorang yang baru meninggal) tokoh ilmuwan, rubrik tinjauan buku baru, dan juga tidak ada pemuatan foto penulis artikel dalam Jurnal Perspektif Ilmu Pendidikan. Butir pemuatan foto penulis artikel memperoleh nilai 1 dikarenakan pemuatan foto penulis artikel merupakan hal yang tidak boleh ada dalam sebuah jurnal ilmiah sehingga yang selama ini telah dilakukan oleh Jurnal Perspektif Ilmu Pendidikan sudah tepat dengan tidak mencantumkan foto penulis artikel.

\section{Analisis Data Evaluasi Mutu Jurnal Perspektif Ilmu Pendidikan}

Berdasarkan deskripsi di atas, bisa dilihat bahwa untuk aspek nama berkala, kemantapan penampilan, serta gaya penulisan, Jurnal Perspektif Ilmu Pendidikan mencapai nilai tertinggi seperti yang tercantum di dalam Pedoman Akreditasi Majalah Ilmiah. Hal ini menunjukkan bahwa untuk aspekaspek tersebut, Jurnal Perspektif Ilmu Pendidikan sudah dikatakan memenuhi syarat yang telah ditetapkan oleh LIPI.

Sedangkan untuk aspek-aspek yang memiliki nilai terendah atau jauh dari nilai tertinggi yang ditetapkan oleh pedoman akreditasi LIPI yaitu aspek tiras dan aspek lain-lain. Nilai tertinggi untuk aspek tiras dan aspek lain-lain yaitu 5 dan 7 sedangkan yang dicapai oleh Jurnal Perspektif Ilmu Pendidikan hanya 2 dan 3. Hal ini disebabkan karena Jurnal Perspektif Ilmu Pendidikan hanya dicetak sebanyak 100 halaman atau tidak memenuhi batas minimum yang ditetapkan oleh LIPI sebanyak 300 eksemplar. Adapun distribusi jurnal perspektif selama ini, sebagai berikut.

Tabel 14. Daftar Distribusi Jurnal Perspektif Ilmu Pendidikan

\begin{tabular}{|c|l|c|}
\hline No & \multicolumn{1}{|c|}{ Distribusi } & Jumlah \\
\hline 1 & FIP di seluruh Indonesia & 29 \\
\hline 2 & Fakultas se-UNJ & 7 \\
\hline 3 & Kajur se-FIP & 8 \\
\hline 4 & Dewan Redaksi (AKTIF) & 24 \\
\hline 5 & Penulis-penulis & 14 \\
\hline 6 & Arsip & 5 \\
\hline 7 & DIKTI & 2 \\
\hline 8 & LIPI & 2 \\
\hline 9 & Perpustakaan FIP, UNJ \& & 3 \\
\hline 10 & PASCA & 2 \\
\hline & Rektor dan PR 1 UNJ & 98 \\
\hline
\end{tabular}

Sedangkan untuk aspek kelembagaan penerbit, penyunting/dewan redaksi, substansi, dan keberkalaan memiliki nilai yang bisa dianggap tidak terlalu rendah, yaitu masing-masing 11, 10, 21, dan 7 .

Jika dihitung kesemua aspek tersebut maka total keseluruhan dari semua aspek tersebut yaitu.

Tabel 15. Hasil Penghitungan Seluruh Aspek-aspek Penilaian Jurnal Perspektif Ilmu Pendidikan

\begin{tabular}{|c|l|c|}
\hline No & \multicolumn{1}{|c|}{ Unsur } & $\begin{array}{c}\text { Nilai } \\
\text { Tertinggi }\end{array}$ \\
\hline 1. & Nama berkala & 5 \\
\hline 2. & $\begin{array}{l}\text { Kelembagaan } \\
\text { Penerbit }\end{array}$ & 11 \\
\hline 3. & $\begin{array}{l}\text { Penyunting/De } \\
\text { wan Redaksi }\end{array}$ & 10 \\
\hline 4. & $\begin{array}{l}\text { Kemantapan } \\
\text { Penampilan }\end{array}$ & 9 \\
\hline 5. & Gaya Penulisan & 10 \\
\hline 6. & Substansi & 21 \\
\hline 7. & Keberkalaan & 7 \\
\hline 8. & Tiras & 3 \\
\hline 9. & Lain-lain & $\mathbf{7 8}$ \\
\hline Jumlah Keseluruhan & \\
\hline
\end{tabular}

Jika dilihat dari total keseluruhan nilai tersebut maka Jurnal Perspektif Ilmu Pendidikan bisa mendapatkan akreditasi B (baik), meskipun memang hal ini tidak bisa dijadikan patokan pasti. Masih banyak kekurangan yang terdapat di dalam Jurnal Perspektif Ilmu Pendidikan. Motivasi dosen dalam menulis di Jurnal Perspektif Ilmu Pendidikan pun masih kurang, dilihat dari kurangnya ketersediaan naskah, dalam hal ini membuat seleksi ketat terhadap kelayakan naskah-naskah tersebut kurang diperhatikan.

Selain itu, Jurnal Perspektif, FIP UNJ ini misalnya semula direncanakan terbitan sekali dalam enam bulan ( April dan Oktober), tetapi karena kesulitan memperoleh naskah belum dapat terbit secara teratur dan tepat waktu. Pada umumnya kesulitan dalam menerbitkan media berkala adalah kesulitan mendapatkan cukup naskah yang memenuhi syarat (Sitepu, 2009: 96).

Walaupun secara umum jurnal memuat naskahnaskah yang bersumber dari laporan penelitian, latar belakang dan tujuan khusus penerbitan jurnal itu dapat berbeda-beda. Sebagai contoh, penerbitan Jurnal Perspektif, FIP UNJ dilatarbelakangi oleh keinginan untuk (1) meningkatkan minat dan motivasi dosen menghasilkan karya ilmiah dalam ragam tulisan dan (2) mengatasi kesulitan dosen memperoleh wadah tulisan ilmiah dalam memenuhi angka kredit untuk kenaikan pangkat/jabatan akademis. Kajian 
sementara menunjukkan, dosen belum begitu tertarik untuk mengekspresikan buah pikirannya dalam ragam tulisan ilmiah. Terdapat juga dosen yang mampu melakukan penelitian empiris dan/atau kajian teoritis, namun mengalami kesulitan dalam menyajikannya sebagai suatu karya ilmiah yang layak diterbitkan. Oleh karena itu, Jurnal Perspektif, FIP UNJ ini diharapakan dapat menumbuhkembangkan minat dan motivasi dosen FIP UNJ melakukan penelitian dan menuliskan hasilnya sebagai karya ilmiah yang layak dipublikasikan pada salah satu jurnal yang berskala nasional dan terakreditasi, bahkan kalau mungkin di tingkat internasional, atau setidak-tidaknya di Jurnal Perspektif FIP UNJ (Sitepu, 2009: 96).

\section{PENUTUP}

\section{Kesimpulan}

Berdasarkan hasil penelitian maka dapat ditarik kesimpulan bahwa hasil penilaian dari jurnal Perspektif Ilmu Pendidikan berdasarkan Pedoman Akreditasi Majalah Ilmiah yang dikeluarkan oleh LIPI kira-kira mendapatkan akreditasi B (baik). Meskipun hasil evaluasi dalam penelitian ini tidak bisa dijadikan tolok ukur dalam ukuran akreditasi ketika Jurnal Perspektif Ilmu Pendidikan ingin memperoleh akreditasi dari LIPI. Masih banyak kekurangankekurangan yang perlu diperbaiki terutama dari perolehan naskah penelitian yang memenuhi syarat, berjalannya mitra bestari sebagai penentu kelayakan naskah, serta dari aspek tiras dan aspek lain-lain.

Tidak berjalannya mitra bestari akan mengakibatkan sulitnya Jurnal Perspektif Ilmu Pendidikan mengajukan akreditasi meskipun aspek nama berkala, kemantapan penampilan, dan gaya penulisannya sudah memenuhi syarat.

\section{Saran}

Beberapa saran yang bisa diajukan sesuai dengan hasil penelitian, yaitu pertama, bagi dosen, perlunya semakin meningkatkan motivasi dalam melakukan penelitian dan menuliskan hasilnya sebagai karya yang layak dipublikasikan.

Kedua, bagi fakultas, membantu untuk melengkapi aspek-aspek yang kurang dalam Jurnal Perspektif Ilmu Pendidikan karena tanpa adanya bantuan dari fakultas sulit untuk menyempurnakan aspek-aspek evaluasi yang masih memiliki banyak kekurangan.

\section{DAFTAR PUSTAKA}

Ansyar, M. (1989). Dasar-dasar pengembangan kurikulum. Jakarta: Depdikbud, P2LPTK

Departemen Pendidikan Nasional. (2009). Petunjuk teknis program percepatan publikasi pada jurnal ilmiah bereputasi internasional bagi para penerima hibah penelitian kompetitif. Diakses pada tanggal 08 Oktober 2009 dari http:/ / lemlit.unila.ac.id

Dictionary Babylon. Definition of scientific journal. Diakses pada tanggal 08 Oktober 2009 dari http:/ / dictionary.babylon.com / scientificjournal

Departemen Pendidikan Nasional. (2006). Panduan akreditasi berkala ilmiah. Diakses pada tanggal 08 Oktober 2009 dari http:/ / dp2m.dikti.go.id/ document.php/docu-ment/filemanager/1/ $189 / 0 / 0 /$

Direktorat Jenderal Pendidikan Islam. Pedoman penerbitan jurnal ilmiah perguruan tinggi agama islam. Diakses pada tanggal 08 Oktober 2009 dari http://www.ditper-tais.net/regulasi/ jurnal/pdjur.asp

Fuddin. (2008). Program evaluasi dengan metode CIPP. Diakses pada tanggal 08 Oktober 2009 dari http:/ / fuddin.wordpress.com/20-08/07/02/ teori-evaluasi-dengan-cipp/

Kriyantono, Rachmat. (2006). Teknik praktis riset komunikasi. Jakarta: Kencana.

Kusumawati, A. (2009). Evaluasi sumber belajar. “Jurnal Perspektif Ilmu Pendidikan Edisi Khusus Tahun 2009". Jakarta: Fakultas Ilmu Pendidikan Universitas Negeri Jakarta

LIPI. (2009). Pedoman akreditasi majalah berkala ilmiah. Diakses pada tanggal 08 Oktober 2009 dari http://jurnal.pdii.lipi.go.id/da-ta/PedomanAkreditasi-Dikti.pdf

Neuman, W. L. (2003). Social research methods. $5^{\text {th }}$ ed. Boston: Allyn and Bacon

Poerwandari, E. Kristi. (2007). Pendekatan kualitatif untuk penelitian perilaku manusia. Depok: LPSP3 Fakultas Psikologi UI.

Purwanto \& Suparman, A. (1999). Evaluasi program diklat. Jakarta: STAI-LAN.

Sitepu, B.P. (2009). Teknik penulisan naskah ilmiah. "Jurnal Perspektif Ilmu Pendidikan Edisi Khusus Tahun 2009". Jakarta: Fakultas Ilmu Pendidikan Universitas Negeri Jakarta

Universitas Petra. (2005). Analisis isi pesan dalam feature di seputar Jatim RCTI biro Surabaya. Diakses pada tanggal 08 Oktober 2009 dari http:// 
digilib.petra.ac.id

University of Brockport. Reading academic journal articles.

Diakses pada tanggal 08 Oktober 2009 dari http://www.brockport.edu/socio-logy / journal.html

Widianto, E.D. (2009). Penelitian ilmiah dan publikasi jurnal. Diakses pada tanggal 08 Oktober 2009 dari http://edwidianto.word-press.com/2009/ 06/23/penelitian-ilmiah-dan-publikasi-jurnal/

Wikipedia. (2009). Scientific journal. Diakses pada tanggal 08 Oktober 2009 dari http:// en.wikipedia.org/wiki/Scientific_journal

Yuris, A. Analisis isi (content analysis). Diakses pada tanggal 08 Oktober 2009 dari http:// andreyuris.wordpress.com/artikel/

Yusuf, F. (2000). Evaluasi program. Jakarta: Rineka Cipta.

Zed, M. (2004). Metode penelitian kepustakaan. Jakarta: Yayasan Obor Indonesia 